\title{
Abuse of Power on Managing the Health Care Services Policy for the Indonesian National Army Forces and its Implication on Marginalized Soldier's Health
}

\author{
Ida Bagus Purwalaksana ${ }^{1, *}$, Sumartono ${ }^{2}$, Bambang Santoso Haryono ${ }^{3}$, Wike ${ }^{3}$ and \\ Bambang Slamet Riyadi ${ }^{5}$
}

${ }^{1}$ Doctorate Program in Public Administration, Faculty of Administrative Sciences, Universitas Brawijaya, Jalan MT. Haryono No. 163, Malang City, East Java 65145, Indonesia; Lieutenant General of the Indonesian National Army for Ministry of Defense of the Republic of Indonesia

${ }^{2}$ Promoter, Professor in Faculty of Administrative Sciences, Universitas Brawijaya, Malang City, Indonesia

${ }^{3}$ Co-Promoter, Associate Professor, Faculty of Administrative Sciences, Universitas Dr. Soetomo, Surabaya, Indonesia

${ }^{4}$ Associate Professor for Faculty of Business Law, Universitas Nasional, Jakarta, Indonesia; Doctor of Criminology from Universitas Indonesia, Jakarta; Doctor of Law from Universitas Gadjah Mada, Yogyakarta, Founder Riset Doktor Bambang Slamet Riyadi, PT. Founder of Legal \& Forensic Audit Consultant "Dr. Bambang Slamet Riyadi, SH. MH \& Partner", Founder Center for Research and Development of Indonesian Intellectuals, Jakarta, Indonesia

\begin{abstract}
This research aims to understand the abuse of power on managing the health service policy and its implication that is very significant in reducing marginalized soldiers' health due at the ontological level and sociological level. The problem is very interesting to be analyzed by conducting a qualitative research method based on public policy theory, abuse of power theory, and health services theory. Data were collected through in-depth interviews, observation, and documentation related to managing the health service policy cases in Indonesia. Data were analyzed by using interactive models are data reduction, data display, data verification, and supported by triangulation. The results were based on ontological level and sociological level using public policy perspective and power perspective for improving health service policy and practice for The Indonesian Army Forces. Vision and mission of public policy on managing health service policy are needed for providing information to stakeholders related, regarding the regulations and sanctions in health service policy. This result provides inputs for making better regulation on health service policy in Indonesia for state agencies as public officials and practitioners.
\end{abstract}

Keywords: Public Policy, Power Management, Health Services.

\section{INTRODUCTION}

\subsection{Research Background}

The health service for the Indonesian Army Forces (TNI) and their families is regulated in Law Number 34 of 2004 . The law is intended to provide health services to TNI soldiers, civil servants, and their families as well as retired employees in order to provide the health service as part of their welfare and to accommodate the rights of health services for members of the TNI and their families as part of social insurance. After the Government Regulation and the Decree of the Minister of Defense, the Health Service of TNI Soldiers was taken over by The Indonesian Health Service Body (BPJS) so that the health services of TNI soldiers and

\footnotetext{
*Address correspondence to this author at the Doctor Program of Public Administration. Faculty of Administrative Sciences, Universitas Brawijaya Jalan MT. Haryono No. 163, Malang City, East Java 65145; Lieutenant General of the Indonesian National Army for Ministry of Defense of the Republic of Indonesia, Jalan Medan Merdeka Barat No.13, Central Jakarta City, Capital Special Region of Jakarta, 10110, Indonesia; E-mail: pdia.fia@ub.ac.id cc. E-mail: bambang.riyadi@citivitas.unas.ac.id
}

their families were marginalized. Based on observation and information stated that The BPJS funds were being corrupted. At the policy level, there are multiple interpretations and indications of abuse of power. At the implementation level, there will be implied on marginalized soldier's health. This study aims to understand the strategic analysis of public policy on managing the health service for The Indonesian Army Forces (TNI) based on public policy theory, power management theory, and health service theory.

There are 2 phases of health services within the TNI, before the National Health Insurance and after the National Health Insurance. The health services in the first phase before joining the National Health Insurance, refer to Article 50 of Law 34/2004 concerning the TNI which states that TNI soldiers and their families receive services in the form of official care, including health care. And retired TNI soldiers also get similar facilities to active TNI members. This service is managed by the Indonesian Army Forces Insurance (ASABRI). Supporting facilities were built 
which have been spread across each TNI assignment area. The services provided by ASABRI for the TNI and their families have been running well in accordance with applicable references. The accuracy and usefulness of health services can really be felt well. Large financing is needed in this service so that the service can run well and maximally. The financing is sourced from the TNI's salary deduction which is $2 \%$ (two percent) of the TNI's basic salary. The services provided have specificities, including (a) a separate referral system which is regulated in stages; (b) the medical records of TNI members' health are monitored regularly for the purpose of assignments and career development; (c) active TNI members and their families and retired TNI members feel more comfortable in accessing TNI health services.

After the first phase, the second phase entered on January 1, 2014, that TNI health services were managed by BPJS health program. The basis for managing TNI health services by BPJS health program refers to Law 24/2011 concerning BPJS health program which mandates that starting January 1, 2014, health services for active TNI and their families are managed by BPJS health program through the National Health System. Its implementation and regulated in presidential regulations and health ministerial regulations.

Based on observation and information about that health services within the TNI, the implementation of health services within the TNI encountered many problems, including that (a) the health service system within the TNI was not optimal because the system did not accommodate the peculiarities of health services within the TNI; (b) the issuance of the director's regulation number $4 / 2018$ regarding the individual referral system which limits referrals based on distance and area so that many TNI members and their families cannot access TNI health facilities; (c) the purpose of the inclusion of health services in the environment in the BPJS health program is to obtain better health services but its implementation and quality of is considered to be getting worse.

On the other side, the peculiarities of the health service system within the TNI should be: (a) the management of health facilities within the TNI is a command and centralized system; (b) health services for members of the TNI and their families as well as retirees are part of welfare and are provided to the fullest; (c) the referral system in health services within the TNI is regulated separately in accordance with the interests of the TNI. Based on the explanation above, there is no statutory level of regulation as a legal umbrella on managing the health service of soldiers and their families. At the novel level, it is necessary to have a strategic analysis for implementing the soldier's health service management. Based on the previous explanation above, it is needed a deeper exploration of ontological and sociological level and this issue that is very interesting to be studied. What are the supporting factors in managing soldier's health services in Indonesia? How is the abuse of power and its implication affects the soldier's health service policy in Indonesia? This research is useful for academicians and practitioners in adding knowledge on public policy theory and abuse of power theory for improving the health service for the soldiers and their families. This research also works as a recommendation for the legislative and executive as the public officials that make a revised and detailed regulations on soldier's health service management.

\subsection{Research Originality}

The concept of new public services for the public interest, from the elements of efficiency, effectiveness, economy, fairness and responsiveness to the needs and welfare of the community, was studied by Solong. This is based on the necessity of public services implemented by the government which is oriented to the public interest. So that there is a paradigm shift in public services for public institutional organizations towards public satisfaction. This study uses a qualitative method with a literature study approach to the theory of public administration related to the concept of new public services. This study explains that in Indonesia, which is currently faced with the dynamics of globalization and an increasingly competitive economic environment, the government must act professionally so that it can reduce the negative impact on society. The demands of globalization today are not only a challenge for businesses, because it is evident that the organizers of public administration must perform excellent services to meet the quality of life and welfare of the people. The concept of a paradigm shift in administration in the era of globalization as contained in the concept of the New Public Service needs to be carried out in various dimensions. The first dimension is that the behavior of the bureaucracy, both individuals and institutions, should not be too much influenced by the view of power. The second dimension, the quality of public service reorientation in the philosophy of state administration itself must prioritize aspects of effectiveness, economy, fairness 
and responsiveness. Thus, through the actualization of the New Public Service in the administration of public services, it can change the quality of life and people's welfare for the better (Solong, 2017).

The change in health system policy in Nepal from the previous one using the National Health Insurance policy system to Social Health Insurance was studied by Mishra. This program aims to improve access to health services for the poor and marginalized, and people in hard-to-reach areas. This study uses a qualitative approach with literature studies and field observations in Nepal. This study suggests that more deliberation on an effective national health insurance policy is needed in Nepal. A lot of deliberation is needed to discuss a future-appropriate insurance structure for Nepal. Furthermore, this study urges to plan evaluation of processes and outcomes within one or two years of implementing Social Health Insurance for scheme adjustments based on identified strengths and weaknesses towards universal health coverage pathways (Mishra, S. R., Khanal, P., Karki, D. K., Kallestrup, P., \& Enemark, 2015).

The description and implementation of the Practical Sustainability and Sustainability Implementation Model (PRISM) studied by Mc Creight in four health systems in the United States. The benefit of this research is to discuss contextual factors in the translation of interventions in health service delivery. This study uses a mixed-method research method with the PRISM model approach with the aim of assisting in conceptualizing, defining and assessing key contextual factors. This study identified important multilevel contextual factors, including variability in operational processes and available resources. These domains help facilitate the planning and implementation phases of the four interventions and guide deliberate adaptation. In particular, using the PRISM approach, this study produces recommendations for documenting and defining key factors at various levels of internal and external stakeholders. It considers how the external environment, intervention design, implementation and infrastructure sustainability, and multilevel recipients of the intervention i.e., adopting organizations with an emphasis on health care teams and providers and patients affect implementation outcomes (McCreight et al., 2019).

There is a study that focuses on current practice to critically examine factors known to be relevant for normalization namely definition, registration, establishment and assessment of health care development. There has been some notable progress in conceptualizing and engaging in health service development operations. However, there are still some problems that affect the way the main treatment works. This study uses a mixed-method by adopting an inductive approach. The research team consisted of academics, health authorities, doctors and representatives of community organizations, all of whom have experience using participatory research approaches. This study examines papers between 2007 and 2011 and is directly involved in iterative research to sample, assess and analyze the literature to follow the principles of an interpretive synthesis approach and use the Normalization Process Theory. Twenty-six papers were selected from 289 papers, as a sample of purposeful work reported as user engagement in the field. Several papers provide a clear working definition of service user engagement. The reasons identified for enrolling service users in primary care projects are related to the policy imperative for shared governance and emancipatory ideals. The majority of the methodologies used are standard healthcare research methods that do not qualify as research with service users. This indicates a lack of congruence between the stated objectives and methods. Most studies report only positive results, raising questions about the balance or completeness of published assessments. In order to make the better implementation of a public policy, it is necessary to know the variables and factors that influence it. For this reason, a policy model is needed to simplify the understanding of the concept of policy implementation. Policy implementation is a dynamic process, where there are many factors that interact and influence policy implementation. These factors need to be displayed in order to find out how the implementation of these factors (Tierney et al., 2016).

The development of the public administration paradigm emphasizes the focus, locus, and value be achieved. The classical bureaucracy focuses on organizational structure and management functions, locus is on the government bureaucracy and business organization, while values are on efficiency, effectiveness, economic and rational. The neobureaucracy, focus on behaviour-based decisionmaking processes, management, systems, and research, locus on government bureaucratic decisions, and values are efficiency, effectiveness, economics and rationality. The institutions focus on understanding bureaucratic behavior and making decisions that are gradual and incremental in nature. The human 
relations, focus and locus on organization, as well as values are participation in decision making, minimization of differences, status, openness, selfactualization, and increased job satisfaction. The public choices focus on providing services to the community. And the New Public Management (NPM) is concerning with human values and social justice focused on organizational design based on decentralization, democracy, responsiveness, participation, and providing services needed by the community (Frederickson, 1976).

Public policy is a complex pattern of interdependence collective choices, including decisions to actions made by government agencies or offices (Dunn, 2012). Dunn argues that public policy is a series of actions that are determined and implemented or not carried out by the government that has a purpose or is oriented towards certain goals for the benefit of the whole community. The implications of this understanding are: its first form is the determination of government action, not enough to only be stated but also implemented in real form, based on certain aims and objectives, and essentially aimed at the interests of the entire community. Public Policy analysis is an intellectual and practical activity aimed at creating, critically assessing, and communicating knowledge about and within the policy process. The policy analysis process has 5 interdependent stages that together form a complex and non-linear cycle of intellectual activity. These activities are sequential in time and are embedded in a policy process that is complex, nonlinear and essentially political (Dunn, 2012).

The emergence of the New Public Management (NPM) paradigm in the early 1990s is an important momentum questioning the dominance of the government and providing space for the private sector to participate in public services (Hood, 1991). A new model in public policy is needed to improve the performance of public services with results-oriented and competitive dynamics by changing the rules of the game and fostering creativity in providing services. The paradigm can be divided into 5 periods. The first period is the separation between politics and public administration, with a focus on civil service and government budgeting, with political and policy loci. The second period is administrative principles focusing on administrative principles, namely planning, organizing, coordinating, reporting and budgeting with a locus in any organization. The third period is political science because its focus is on the formulation of public policies which are full of political values and the locus is bureaucracy. The fourth period considers public administration as a part of administrative science that must be developed scientifically with a focus on public administration and business administration. The fifth period focuses on public administration as public administration, with a focus on organizational theory, management theory and public policy, while the locus is public problems and public interests. A new paradigm emerged that public policy as governance with a multi-dimensional approach and focus on public affairs that require private parties and society and locus on the public, private and civil society sectors (Tulkens, 1986).

The abuse of power in Indonesia has an impact on deviant actions that are not only under pressure from power but also the moral behavior of public officials. Many public officials abuse power. They were punished by tough laws. There is a weak system when public officials who abuse power departing from people who do not have the view of life as a nation and state as it should be. Therefore, it is necessary to have a system by carrying out collaborative practice and not just rhetoric (Riyadi, 2020b). Abuse of power in managing soldier's health service policy involves a lot of conflicting interests, resulting in corruption. Abundant soldier's health service policy must be controlled by the state for the greatest prosperity of the people. The research results of the abuse of power occur as a result of a conflict of interest to maintain power in soldier's health service policy, which causes state losses and the suffering of the people. The components of sudden change caused by global change and modernization are subject to materialism and consumerism by ignoring cultural values in state life. It takes cultural morality and limits the extent of that power (Riyadi, 2020a).

The corrupt behavior shows that it is still ongoing and has become severe. Corruption crimes are organized crimes based on the interests of individuals and groups in maintaining power. Weak law enforcement in solving corruption cases of politicians and corruption of state officials involved in corruption by lightening court decisions causes many cases to be delayed in the prosecution process, even terminated. This is an indication of the weakness of law enforcement against white-collar criminals. Conflicts of interest are often based on political bargaining and abuse of power (Riyadi, Wibowo, \& Susanti, 2020). In a particular case, law dispute of rights describes the rights as communal property or individual property or state. Indonesia has adopted individual and communal 
rights as well as self-government property rights are analyzed through strategic analysis theory and since it is related to public policy and ownership, hence another approach is through public policy (Riyadi, 2017).

A case study presenting a qualitative approach method expose to the case analysis that there has been an abuse of power against the authority of the state institution. It is better if the legislators of the laws and regulations think about operational accountability that need a check and balance system of the law enforcement (Riyadi, Hermanto, Harlina, \& Purnomo, 2020). Capability, partnership, and information sharing do not have a significant effect on performance but must be mediated by conflict resolution in order to have a positive and significant impact. This finding implies that managers should pay more attention to power management (Syeh Assery, Tjahjono, Palupi, \& Dzakiyullah, 2020).

Distributive justice has a positive and significant effect on job satisfaction. Procedural justice and interactional justice have no effect on job satisfaction. Job satisfaction has a positive and significant effect on work performance. This research implies that managers should pay more attention to distributive justice to increase job satisfaction and work performance (Purnama, Tjahjono, Assery, \& Dzakiyullah, 2020). Misbehaviour in an organization includes political misbehavior. All of them had an influence on losses, both financial and social. It will be necessary to intervene on both sides, financial and social. Based on a case study, data was collected by interviewing many staff in Indonesia and analyzed using qualitative data analysis such as data reduction, display and verification, findings described into production misbehavior (Feriyanto, Assery, Saleh, \& Suryaningsum, 2017).

The study about the relationship between partnership, capability and performance were collected using a questionnaire and analyzed using partial least square. The results of the study are as follows. There are no significant relationships between partnership and performance but have to be fully mediated by capability. While capability to performance has a positive and significant impact (Saleh, Assery, \& Dzakiyullah, 2018). Managing conflicts still needed to be explored in terms of causes, processes and results. The case study was conducted in a qualitative approach to obtain the holistic and meaning of the organizational and managerial process. Data were collected use interviews and analyzed for data reduction, display and verification. Findings are classified into 3 themes, causes, processes, and results (S. Assery, Tjahjono, Sobirin, \& Hartono, 2017). The service management was studied using the case study method by collecting interviews with 4 managers. Data were analyzed using QDA for data reduction, data display and data verification. Findings were classified into 3 themes are partnership, capabilities and performance (Saleh, Assery, Sabihaini, \& Suryaningsum, 2017).

Health services are the right of every person guaranteed in the Constitution to make efforts to improve the health status of individuals, groups or society as a whole. Health services according to the Ministry of Health of the Republic of Indonesia as stated in the Health Law number 36 of 2009 are every effort that is carried out alone or jointly in an organization to maintain and improve health, prevent and cure disease and restore health, individuals, families, group or society. Based on Article 52 paragraph (1) of the Health Law number 36 of 2009, health services generally consist of 2: (1) individual health services are organized by individuals independently and families or community groups aimed at curing diseases and restoring individual and family health. implemented in health service institutions called hospitals, maternity clinics, and independent practices; (2) public health services are organized by community groups with the aim of maintaining and improving health which refers to promotive and preventive actions and carried out at certain public health centers such as clinics and hospitals.

Health policy includes public policies that are assumed to cover all directions of action and are implemented that affect the institutional arrangements, organizations, services and financing arrangements in the health system. This policy covers the public sector. But because health is influenced by many determinants outside the health system, health policy reviewers are also concerned with any actions and plans of action by organizations outside the health system that have an impact on health. There are many definitions of health policy, there are many ideas about the assessment of health policy and its emphases. One planner sees it as a way to influence the determinants of the health sector in order to improve the quality of public health; and for a doctor, a policy is everything to do with health services. Health policy is similar to politics and all offers are open to people who influence policy-making, how they exercise that influence, and under what conditions. The process of making a health policy is a 
complex process because it involves many processes and variables that must be studied. Therefore, several experts who are interested in studying health policy divide the public policy-making processes into several stages. The purpose of this kind of distribution is to make it easier for us to review policies.

The differences of the above previous research on public policy, power management, and health service, tend to the government and its agencies have to manage the health service problems by enforcing rules and standards to be setup laws and regulation. Following up previous study gap and the phenomena, so this study analyzes a multi policies approach regarding managing soldier's health services in Indonesia.

\subsection{Significance of Research}

Theoretically, this research should be able to develop science in public policy in the formation of regulations, expand knowledge among academics, especially public policy students, develop the concept of public policy, as well as become a reference material for deepening and enriching scientific repertoire regarding regulatory inconsistencies. Based on the epistemological and sociological description of public policy theory for refining the research, it can be stated that making multi-policies and regulations related to soldier's health service policy is a part of public policy theory. Based on the epistemological and sociological description of several definitions related to abuse of power above can be stated that making multi policies of soldier's health service policy can be analyzed by the power theory. Based on the epistemological and sociological description of conflict resolution theory, it can be stated that the making of multi policies on soldier's health service policy can be analyzed by health service theory.

For the Government, this research should be able to provide input for the executive and legislative parties in making reforms in the field which is feasible, comfortable, safe and inexpensive for the community. This research can also be used as input for related institutions in reviewing any policies related to health care services for soldiers and families. This research is expected to be able to give birth to a caring attitude of the public in order to understand the inconsistencies in regulations made by public officials.

\section{RESEARCH METHODS}

A qualitative research strategy can be applied if the research problems need to be explored deeper or followed up on previous quantitative research due to a previous theory or concept that is still considered unable to capture the complexity of the problem under study (Creswell, 2013). A qualitative research approach produces descriptive data in the form of words or writings and behaviors that can be observed from the subject and object of the study itself. The qualitative approach was chosen because it is in accordance with the aims of the research to describe and understand the phenomena, events, social activities, attitudes, beliefs, and perceptions of people (Creswell, 2013).

Data collection in this research were interviews, observation and documentation. An in-depth interview was conducted and performed with key informants. Participant observation was conducted by the authors and the team to obtain records in the field of study. Related documentation was gathered from many sources such as internet media and library documents. Data analysis were using 3 steps, which were data reduction, data display and data verification refer to the interactive model. Data reduction is to sort out the main data, data display is to present the data, and data verification is to conclude the main themes of the results (Miles \& Huberman, 1994).

Validity and reliability used triangulation based on the observation, in-depth interviews, and documentation analysis to obtain valid and reliable data coping credibility, transferability, auditability, and confirmability (Creswell, 2009). Credibility was related to the truth aspect by means of triangulation to compare the results of an interview with the results of interviews with colleagues. Transferability shows the applicability of research to other studies that readers can understand the results of qualitative research. The report is made in a detailed, clear, and systematic manner. Auditability means that it can be tested by examining the entire research process, since designing case studies, determining data sources, data collection, data analysis, make conclusions, can be traced and showing the processes and results. Confirmability relates to the objectivity that the research results are agreed upon and accepted (Creswell, 2009).

\section{ANALYSIS AND DISCUSSION}

Based on the data collection and data analysis, it can result as follows. Theme number 1, standard. Policy implementation can be analyzed by the level of success of the standards and policy objectives. Policy implementation certainly confirms certain standards and targets that must be achieved by policy implementers 
"In the past, there was a hospital law and a health law. So what became difficult was suddenly an article stating that what was meant by government hospitals were under the Ministry of Health. I still remember that, why is there this clause, basically there is, at that time I said be careful then there was a clause that what is meant by government hospitals includes hospitals belonging to the $T N I$, they have been separated all this time by the system. After the health law came out and also the BPJS law, a continuation of the SJSN law and the health law, where the health law states that the leading sector for the health sector is the ministry that takes care of health, namely the Ministry of Health. The BPJS provisions say that all government hospitals are required to join BPJS. Now refer to the SJSN law, hospital law, health law, so we feel defeated, we are not asked whether or not the law applies. If the TNI is ordered by the regulation, there is a law and the BPJS, the answer is only one, yes we are ready to implement it because the system in TNI was an absolute hierarchy, there were orders to be carried out" (interview of informant 1, 2020).

Based on the interview of informant 1, it can be concluded that the background of the TNI hospitals participated in the implementation of the JKN BPJS program policy because of the mandate of Law 24/2011 and the President's order. So that with the existence of an absolute hierarchical system in the TNI organizational body, the TNI continues to implement the JKN BPJS program even though there are challenges. The implementation of the BPJS policy for health services to the TNI, of course, BPJS has a target for BPJS health programs to the TNI. It is explained that the target of implementing the BPJS health service program within the TNI organization is in accordance with the mandate of the law which states that to provide optimal health services to the Indonesian people, health service is fully borne by the government. This includes health services for TNI soldiers and their families.

"So the initial purpose of the existence of BPJS in accordance with the mandate of the law is to provide optimal or complete health services to all Indonesian people, meaning that starting from infants up to their lifetime it is borne by the government to be included in BPJS health, including TNI soldiers and their family (interview of informant 2, 2020).

Based on the interview with informant 2, it can be concluded that in the implementation of health services the TNI adheres to the BPJS law which explains that all Indonesian people are required to participate in BPJS including the TNI. With the joining of the TNI into the BPJS program, it is undeniable that there are benefits that are felt after using the guarantees provided by BPJS. After joining BPJS, there are benefits, especially from a financial perspective. The benefit from a financial point of view is that hospital income can increase after the BPJS era.

"In terms of service in the past, if you come, you will be served directly. You don't need to bring an ID card, you don't need to bring a KTA, the important thing is that he has an NRP or NIP identification number, he will definitely be served or he mentions his father's NRP and NIP, if those who check are family members, they will be served. But if after the BPJS era, he had to bring all the requirements and in that one day he had to go to a public clinic, for example after that he couldn't go to another clinic, only 1 clinic a day. BPJS does not say it has to be 1 clinic, but in the regulation, it only pays 1 person's claim. The patient only has one clinic, meaning that if there are 3 clinics, the hospital will lose services and materials because BPJS requires a maximum of 1-day outpatient $R p$. Outpatient is a laboratory examination or in clinical services, the principal is $R p$. 150,000. That's why I said earlier that from access to services, those who access it will feel a loss because it was delicious before. if he had to come back tomorrow, it would be a long loss of time. In the past, if you had a chronic disease, you would be given medicine for 3 months, then check it again for the next 3 months. Chronic disease medicine takes a month at most, sometimes only for two weeks. So if we have access to services, we feel a loss, but in terms of hospital income, we feel that it has increased. if the soldiers who 
seek treatment and their families, the hospital is not paid" (interview of informant $3,2020)$.

Based on the interview above, it can be concluded that the complicated service procedures are shown in several cases, including:

A. Before the BPJS era, the administrative procedure was considered quite easy, that is, only armed with an NRP or NIP identity number, TNI patients could immediately enjoy health services. However, this condition changed when TNI health services were regulated by BPJS, after the existence of BPJS the administrative procedures were felt to be more complicated because TNI patients when they wanted treatment had to bring complete requirements to be served.

B. Before the BPJS era, TNI patients could use the health clinic without being limited by time. This means that 1 day can be treated at several clinics and of course this saves the patient's time. However, when entering the BPJS era, it certainly brought changes to health services which were limited to 1 day 1 clinic. Actually, the policy is not because of the BPJS decision which reads like that. Instead, the decision was based on a regulation that BPJS states that it only pays 1 person for 1 clinic worth 150 thousand. Of course, the BPJS decision on the claim of 1 person 1 clinic brings changes to clinic operations. In order to prevent the hospital from losing money, in the end, clinic services were limited to 1 day 1 clinic.

C. Before the BPJS era, TNI patients who came for treatment would be given a duration of medication that had been adjusted to the patient's condition. For example, when there is a TNI patient who is chronically ill, the doctor will give the duration of the drug according to the patient's condition, such as the patient's recovery takes 3 months, then the drug is given for 3 months. Things changed when you joined BPJS. The duration of drug administration is no longer adjusted to the patient's needs but is adjusted to the provisions of BPJS. For example, for chronic disease drugs that require a healing time of about 3 months, patients only get 1 month and have to come back the next 1 month. This condition is certainly detrimental to the patient, especially in terms of time and the healing period is not optimal.

Based on the description above, it is clear that health services in the BPJS era have setbacks. In the past, the provision of health services was provided until the patient recovered, after entering the era of BPJS, the service provided was adjusted to the claims and rules of BPJS. So that patients only get services according to BPJS claims and of course this is detrimental to the patient.

"According to the law, there is a tiered referral, meaning that all TNI personnel and their families who want treatment must first come to the First Level Health Facility, after that they may come to the hospital with a referral letter. So far, the TNI can seek treatment directly at the hospital. However, based on the regulation of the director of BPJS, that hospital is an Advanced Referral Health Facility, so all must go through the First Level Health Facility, and in my opinion, it is detrimental to TNI soldiers and their families." (interview of informant 4, 2020).

Based on the interview, it can be concluded that the tiered referral system is deemed not to accommodate the needs of the TNI because the TNI feels disadvantaged by the tiered referral system. Based on the description above, it can be concluded that one of the problematic BPJS services is the tiered referral system, which is considered quite inconvenient for TNI patients and their families. The BPJS law regulates patient referrals in the form of a tiered referral system. Where when there is a member of the TNI who wants treatment, he must first seek treatment at the First Level Health Facility then if the patient's condition has not been resolved, the patient may come to the clinic owned by the TNI. TNI Hospital is the main referral when patients need further referrals from First Level Health Facilities. This means that the TNI cannot use the hospital facilities without the approval of the First Level Health Facility.

The Ministry of Health of the Republic of Indonesia, as one of the makers of health regulations within the TNI, responded to the solutions contained in the Minister of Health Regulation number 3 of 2020 concerning competent referrals. Competent referrals refer to the availability of expert human resources in a hospital. For example, in a type A hospital, there are 
patients who need a certain expert for treatment, but the disease expert is not owned in a type A hospital but is in a type $D$ hospital. So patients who need this expert are referred to a type $D$ hospital availability of experts in hospitals regardless of the type of class of a hospital and tiered referrals.

According to the Ministry of Health, this is an unprecedented breakthrough. This breakthrough is intended so that patients can be treated more quickly, effectively, and efficiently so that the patient's chances of survival can be guaranteed.

Based on the description above, the problem with the tiered referral system in TNI health care facilities actually has a solution, namely through competent referrals contained in ministerial regulation number 3 of 2020, which in general terms, competent referrals refer to referrals based on the availability of doctors. needed in a hospital without having to go through a referral from the lower class to the class that the patient should be treated.

However, it can be concluded that the TNI responded to the tiered referral system with a dissatisfied attitude. This is related to the tiered referral system which is considered impractical, convoluted, and does not accommodate the needs of the TNI. Related to this, BPJS as the executor of TNI health services responded that technical problems occurred in the tiered referral system, so BPJS invited them to regulate these technical problems with internal regulations in the TNI. Meanwhile, the Ministry of Health has issued a ministerial regulation which is one solution to overcome the TNI tiered referral system that is deemed inappropriate, namely by using a competent referral system.

\begin{abstract}
"So this regulation should still be distinguished between TNI soldiers and civilians because in any country where the insurance is covered by the government, everything makes a difference that for TNI soldiers and their families, there are specifics. But in Indonesia, because the law states for all Indonesian people, so there is no special treatment for TNI soldiers and their families" (interview of informant 5,2020 ).
\end{abstract}

Based on the results of the interview, it can be explained that health service policies should be distinguished between TNI soldiers compared to civilians, or there are specifics, but in Indonesia due to the law, there is no special treatment for TNI soldiers and their families. As a result, in the implementation, members of the TNI soldiers felt that they did not get better health service in the BPJS era. Moreover, the services provided are not specific to members of the TNI. The reason for the absence of specificity in TNI services is because the regulations that oversee the BPJS policy do not state that there is a specificity of TNI health services.

Theme number 2, resources. Policy implementation is highly dependent on the ability to utilize available resources, namely human resources, financial resources, as well as policy resources. Policy implementation requires quality resources that are adjusted to the established policies.

"I ask for the uniqueness of the TNI, because it has a special task, the $2 \%$ salary deduction from the basic salary changed to a $1 \%$ cut, why do we TNI have to cut $2 \%$ and subsidize $3 \%$, why not equate it with civilian workers. Because when we say $2 \%$ take Home pay is very big. I agree because it is supported by the government because of takehome pay, but I asked for only $1 \%$, and even then $1 \%$ of takehome pay is already higher than $2 \%$ of basic salary. So now the fee is $1 \%$ of takehome pay" (interview of informant $6,2020)$.

Based on the results of the interview above, financial resources, related to the problem of financing contributions by cutting TNI salaries. The TNI salary deduction for BPJS of $2 \%$ from take-home pay is considered very large and discriminatory. This is because, when compared to the salary cut for civilian workers, it is $1 \%$ while the TNI is deducted $2 \%$ of the salary. Then, the TNI asked BPJS to reduce the contribution to $1 \%$ of the TNI salary and it was finally approved. There is a change in the BPJS contributions for members of TNI soldiers, which at first $2 \%$ of the basic salary changed to $1 \%$ of takehome pay. This is because it is considered burdensome for members of the TNI soldiers.

"Some are from the ministry of defense, some are from the ministry of health. From the ministry of defense are infrastructure, housing, there are also parts of medical equipment which, apart from being fulfilled 
by the ministry of health, are also fulfilled by the ministry of defense, so they are not overlapping but parallel, so complementary is one each other" (interview of informant 7, 2020).

Based on the results of the interview above, the TNI's health budget is supported by 2 ministries. For example, for infrastructure problems, it is financed by the Ministry of Defence, while for health it is provided by the Ministry of Health. The two ministries work together and complement each other's health needs for the TNI.

"An example is a broken bone, the ration from BPJS is 40 million rupiah, we will give the best surgery for 90 million soldiers, so where will the 50 million come from? Of course from the hospital money, the hospital's income. The profit from the hospital is to cover the difference in costs of soldier surgery. The adequacy of the facilities and infrastructure received by the TNI Hospital is still lacking in costs, socialization and in developing human resources" (interview of informant 8, 2020).

Based on the results of the interview above, the budget for health services is still lacking, especially in terms of costs, socialization and human resources. Hospital facilities and infrastructure should be improved, especially human resources and hospital medical equipment.

"related to BPJS, it is a financing problem, but because the health system in Indonesia is not fully supported by BPJS, the TNI Hospital can still use the power of the community that is not covered by BPJS to support hospital financing, because the program is just looking for money so that the program is implemented. Having no money is okay, but having capital and human resources and hospital infrastructure" (interview of informant 9, 2020).

Based on the above statement it can be concluded that although BPJS cannot cover the entire cost, the TNI Hospital uses other programs to provide the best health services for the TNI.

"When we talk about health insurance, what we are talking about is efficient and effective, meaning what is as cheap as possible, insurance for civilians because the principle is to make it as cheap as possible, but in the TNI there is a TNI health principle, not only effective and efficient, but the TNI principle is as much as possible because of health insurance, including guarantees in the TNI law" (interview of informant 10, 2020).

Based on the statement above, it can be concluded that the BPJS program in TNI health services is not optimal, in which the BPJS health service program, in general, is effective and efficient, but it is different from the TNI health insurance principle which prioritizes complete health, so it is optimal and maximum. There is a principle difference between BPJS insurance and TNI health.

"Most of the hospital employees already
understand the procedures for
implementing BPJS services. There are
special actions for TNI members in
hospitals that are not facilitated by
BPJS...... Hospital employees must
understand the procedures for
implementing BPJS services through
seminars, training and other education"
(interview of informant 11, 2020).

Based on the statement of the results of the interview, it can be concluded that human resources, namely hospital employees, have understood the procedures for implementing BPJS services. In addition, these human resources have also been provided with training and coaching in understanding BPJS service procedures. Humans are the most important resource in determining the success of policy implementation. In TNI health services, the human resources implementing the BPJS program in serving TNI members understand the BPJS health services. In addition, the hospital's human resources have also been provided with training and seminars to understand the procedures for implementing BPJS services,

Theme number 3, implementing organizations. Implementing organizations in this case are related to implementing agencies which include formal organizations and informal organizations that will be involved in policy implementation. In implementing policies on $\mathrm{TNI}$ health services, the organizational character within the $\mathrm{TNI}$ is centralized, command, and 
absolute hierarchy, where every command is ready to be carried out.

"All government hospitals are required to join BPJS, we have to join, but at that time I said we were not ready for everything, so we continued to build primary clinics, we asked for an MOU between health and the Ministry of Defense of the TNI. We asked for a grace period of 3 years for this BPJS to prepare a TNI hospital and its health facilities. Because I know exactly, we are not ready, so with the MOU, health facilities lack doctors, even though the requirement for that is to have doctors, and under BPJS rules if there are no doctors in health services, the payment is reduced" (interview of informant 12, 2020).

The characteristics of the organization can be seen from the organizational control in BPJS services within the TNI organization, the strength of the BPJS organization in TNI health services, the transparency of the implementation process, the consistency of the staff in carrying out special services in dealing with the $\mathrm{TNI}$ organization, and the division of authority and responsibility between institutions.

Organizational control in BPJS services in the TNI, there is still special treatment for members of the TNI. At TNI hospitals, TNI members still receive special treatment, namely assistance with the integration of medical services, unlike civilian patients. So that the span of organizational control in BPJS services in the $\mathrm{TNI}$ organization at TNI hospitals can still be controlled.

The strength of the BPJS organization in TNI health services, with the enactment of the BPJS Law which states that all government hospitals are required to participate in the BPJS program so that all rules are the same. For now, the TNI feels that it is not ready to meet the demands of the BPJS. Thus, the TNI requested an MOU from the Ministry of Health and the Ministry of Defense that within a period of 3 years, the TNI would prepare the requirements proposed by the BPJS. What has been prepared by the TNI is related to the construction of health facilities and the procurement of doctors for TNI health facilities, of course, it is intended to comply with BPJS health standards

"Back then, in 2014, the president asked the defense minister and the military commander to support the BPJS program because this is a mandate from the law and all elements of the government must support the government because of the law, and the government has started to act according to the BPJS law because the health commission has never invited the TNI. Who were invited were the Ministry of Health and BPJS because that was the realm of health, in the beginning, we never existed, I just sat here starting this BPJS was pulled into commission 1 at the Soldier Welfare Commission, the welfare of soldiers includes health insurance, that's why when I was at the 2017 meeting, people from the Commission 1 who were celebrities and those from political parties, why did the TNI just want to do it, didn't I? the head of commission 1, then I ask you, do you understand the soldier's oath, we have a soldier's oath, it's stupid to argue, we don't just verbal orders What else can you argue about, the presidential order law, the president summons the TNI, so our answer is only one, ready for whatever happens" (interview of informant 13, 2020).

Based on the statement above, it can be concluded that the characteristics of the implementing organization are related to the transparency of the implementation process. The process of implementing BPJS policies in the TNI organization is not very clear on the grounds that the TNI has never been involved in policymaking and the TNI has only followed the mandate conveyed by the president through the Minister of Defense and the commander in chief. However, when the TNI wanted transparency regarding the clarity of the TNI's health in BPJS, it did not produce any results. Because the policymakers are throwing each other responsibility for the health policy of the TNI which is held by BPJS.

However, regarding accountability data and transparency of data adjustments between BPJS and the TNI, as BPJS invites the ranks of the TNI to reconcile data updates, regarding this matter, BPJS accompanied by ASABRI provides socialization to the TNI with the aim that the TNI understands the technical implementation of the program.

"In the context of adjusting data within the Indonesian National Armed Forces (TNI), data reconciliation activities for 
participants and family members of each work unit in the ranks of TNI Soldiers are carried out. We must always improve the validation of participant data to support the accuracy of the master file and fulfill the rights of participants in obtaining health services. With the socialization and TNI Data Reconciliation held by BPJS Health coupled with the socialization from $P T$. $A S A B R I$, it is hoped that all ranks of the $T N I$ will understand this program well, especially regarding the procedure for using cards and other matters related to work accidents." (interview of informant 14, 2020).

Based on the information, it can be concluded that with the existence of data transparency between BPJS and the TNI in order to adjust data and support data accuracy related to the accountability and transparency of BPJS services to the TNI, accountability and transparency are maintained properly.

Based on several interviews above, it is known that the problem of soldier's health service policy has not been well regulated or implemented. Public policy as a series of actions and implementation by the government has an orientation towards certain goals for the benefit of the whole community. Public policy automatically regulates all matters concerning the affairs of all levels of society. Including regulating soldier's health service policy that can be described and utilized by all levels of society and the government's affairs, including in terms of its policies. The soldier's health service policy should be provided by directions, instructions, and provisions that regulate and coordinate all matters related.

Managing soldier's health service policy and its implementation need comprehensive reviews from several policy processes and implementation. The implementation means to provide for seeking an impact on something. The implementation of policies can be seen as a process to implement policy decisions, government regulations, executive decisions, legislative decisions even into presidential decrees.

\section{CONCLUSION}

Based on the analysis and discussion of the research result above, it can be concluded that managing soldier's health service policy requires power balance which is important in reaching the effectiveness of soldier's health service policy implementation. The collaboration between government, community, private sector, and stakeholders, to reach the best of soldier's health service policy is the priority step in minimizing marginalized soldier's health in Indonesia.

Policy implementation is an important stage because no matter how good a public policy has been made it will be in vain if there is no effort to implement it because it will not bring the desired goal. Without effective implementation in a policy, the decision of policymakers will not be successfully implemented. The success of policy implementation has several variables that influence it, such as policy standards, policy objectives, resources, characteristics of organizations, attitudes of implementers, communication, and the social, economic, and political environment.

It is suggested that the legislative and executive as the public officials in making multi-policies and regulations regarding soldier's health service policy have to be involved and implied for revising regulation on soldier's health service policy in Indonesia. The related institutions as the public officials in making regulations on soldier's health service policy in Indonesia should be conducted for making better multiregulation and covering the holistic soldier's health service policy and management.

\section{REFERENCES}

Assery, S., Tjahjono, H. K., Sobirin, A., \& Hartono, A. (2017). Managing conflict in the supply chain. Journal of Engineering and Applied Sciences, 12(21). https://doi.org/10.3923/jeasci.2017.5433.5436

Assery, Syeh, Tjahjono, H. K., Palupi, M., \& Dzakiyullah, N. R (2020). The Role of Conflict Resolution on Supply Chain Performance. International Journal of Scientific \& Technology Research, 9(3). https://doi.org/10.15408/jch.v8i1.14994

Creswell, J. W. (2009). Research Design: Qualitative, Quantitative, and Mixed Methods Approaches (3rd ed.). California, Thousand Oaks: Sage Publication.

Creswell, J. W. (2013). Qualitative Inquiry and Research Design: Choosing Among Five Approaches (3rd ed.). California Thousand Oaks: Sage Publication.

Dunn, W. (2012). Public Policy Analysis (Fifth). Upper Sadle: Pearson Education Inc.

Feriyanto, N., Assery, S., Saleh, C., \& Suryaningsum, S. (2017). A little aspect of misbehavior in organization. Journal of Engineering and Applied Sciences, 12(15), 3870-3872. https://doi.org/10.3923/jeasci.2017.3870.3872

Frederickson, H. G. (1976). The lineage of new public administration. Administration \& Society. https://doi.org/10.1177/009539977600800202

Hood, C. (1991). All Seasons? the Rise of New Public Management (Npm). Public Administration. 
McCreight, M. S., Rabin, B. A., Glasgow, R. E., Ayele, R. A., Leonard, C. A., \& Gilmartin, H. M. (2019). Using The Practical, Robust Implementation And Sustainability Model To Qualitatively Assess Multilevel Contextual Factors To Help Plan, Implement, Evaluate, And Disseminate Health Services Programs. Transnational Behavioral Medicine, 110.

Miles, M. B., \& Huberman, A. M. (1994). Qualitative Data Analysis. California, Thoussand Oaks: Sage Publication.

Mishra, S. R., Khanal, P., Karki, D. K., Kallestrup, P., \& Enemark, U. (2015). National health insurance policy in Nepal: challenges for implementation. Global Health Action, 8(1), 1-3.

Purnama, Y. H., Tjahjono, H. K., Assery, S., \& Dzakiyullah, N. R. (2020). The relationship of organizational justice on job satisfaction and job performance in banking company. International Journal of Scientific and Technology Research.

Riyadi, B. S. (2017). Law of agrarian conflict and resolution effort: A claim dispute of Eigendom verponding Land. International Journal of Law, 3(80), 88. Retrieved from www.lawjournals.org

Riyadi, B. S. (2020a). Culture of abuse of power due to conflict of interest to corruption for too long on the management form resources of oil and gas in Indonesia. International Journal of Criminology and Sociology, 9(61), 247-254. https://doi.org/10.6000/1929-4409.2020.09.23

Riyadi, B. S. (2020b). Culture of abuse of power in indonesia from the perspective of criminology and law. International Journal of Criminology and Sociology, 9(2008), 274-284. https://doi.org/10.6000/1929-4409.2020.09.26

Riyadi, B. S., Hermanto, A. B., Harlina, I., \& Purnomo, H. (2020). Discretion of power of the indonesian national police impacts the abuse of power in the case of letter forgery of red notice "Fugitive Djoko Tjandra." International Journal of Criminology and Sociology, 9(October), 1292-1300. https://doi.org/10.6000/1929-4409.2020.09.148

Riyadi, B. S., Wibowo, B. R., \& Susanti, V. (2020). Culture of corruption politicians' behavior in parliament and state official during reform government Indonesia. International Journal of Criminology and Sociology, 9, 52-62. https://doi.org/10.6000/1929-4409.2020.09.06

Saleh, C., Assery, S., \& Dzakiyullah, N. R. (2018). Supply Chain: Partnership, Capability, and Performance. Journal of Engineering and Applied Sciences, 13(6).

Saleh, C., Assery, S., Sabihaini, \& Suryaningsum, S. (2017). Supply chain management in service companies. Journal of Engineering and Applied Sciences, 12(15), 3858-3860. https://doi.org/10.3923/jeasci.2017.3858.3860

Solong, H. A. (2017). Actualization New Public Service Administration in Public Service. International Journal of Scientific and Research Publications, 7(3), 505-513.

Tierney, E., Mcevoy, R., O’Reilly-de Brún, M., de Brún, T., Okonkwo, E., Rooney, M., ... Macfarlane, A. (2016). A critical analysis of the implementation of service user involvement in primary care research and health service development using normalization process theory. Health Expectations, 19(3), 501-515. https://doi.org/10.1111/hex.12237

Tulkens, H. (1986). The Performance Approach in Public Enterprises: An introduction and an example. Annals of Public and Cooperative Economics. https://doi.org/10.1111/j.1467-8292.1986.tb01937.x

Received on 25-06-2021

Accepted on 11-08-2021

Published on 30-12-2021

https://doi.org/10.6000/1929-4409.2021.10.190

(C) 2021 Purwalaksana et al.; Licensee Lifescience Global.

This is an open access article licensed under the terms of the Creative Commons Attribution License (http://creativecommons.org/licenses/by/4.0/) which permits unrestricted use, distribution and reproduction in any medium, provided the work is properly cited. 